\title{
GHOSTS Of THE Supreme COURT: A Historical AND JURISDiCTIONAL ANALYSIS JUSTIFYING A CONSTITUTIONAL AMENDMENT FOR COMPULSORY MEDICAL RETIREMENT
}

\author{
KRISTEN E. HAHN*
}

\section{INTRODUCTION}

What happens when a United States Supreme Court Justice becomes incapacitated, such as in a coma, where they are unable to voluntarily retire from the bench? Impeachment of that Justice is not an option: impeachment of federal judges is not permitted "for conduct less than that which triggers the impeachment provisions of Articles I and II" of the Constitution. ${ }^{1}$ Only federal judges below the Supreme Court may be removed pursuant to the Judicial Conduct and Disability Act. ${ }^{2}$ Other branches of government and many states have proactively resolved the issue. Members of the House of Representatives serve two-year terms and Senators serve six-year terms, ${ }^{3}$ thus avoiding any long-term difficulties and consequences if a member of Congress becomes medically unable to perform their duties. Section Four of the Twenty-Fifth Amendment to the Constitution solves this problem for the President. ${ }^{4}$ However, there is a significant void in present law - be it constitutional or elsewhere in federal law-with nothing to resolve the delicate but devastating controversy of an infirmed Justice, serving a life term while offering no meaningful contribution to the Court. The law is silent as to when a once-filled seat on the bench of the highest court in the land is occupied solely by the ghost of what once was.

This Note argues that the historical evidence of incapacity on the Supreme Court, the practical evidence of age-related disabilities and impairments, and the vital job duties that a Supreme Court Justice swears to perpetually uphold until retirement or death justify amending the United States Constitution to provide for compulsory retirement upon the severe mental or physical incapacity of a Justice. Part I sets the stage with an explanation of the current procedures for retirement or resignation from the Supreme Court. Part II then investigates the history of infirmity on the Supreme Court, providing many surprising and significant reallife examples of incapacity on the bench. Part III examines the prevalence of age-

* J.D. Candidate, 2021, Indiana University Robert H. McKinney School of Law; B.A., 2017, University of Southern Indiana - Evansville, Indiana. Thank you to Professor Gerard Magliocca for an imaginative constitutional law course exam and help with formulating this article's topic, and to my faculty advisor Research Librarian and Professor Benjamin Keele for his guidance and ability to conduct research at nearly the speed of light.

1. United States v. Isaacs, 493 F.2d 1124, 1142 (7th Cir. 1974); U.S. Const. art. II, $\S 4$ ("[A]ll civil Officers of the United States, shall be removed . . . on Impeachment for, and Conviction of, Treason, Bribery, or other high Crimes and Misdemeanors”); id. art. III, $\S 1$.

2. 28 U.S.C. $\S \S 351-364(2020)$.

3. U.S. CONST. art. I, §§ 2-3.

4. Id. amend. XXV, $\S 4$. 
related disabilities and impairments, which are of paramount importance to members of the federal government that are appointed for life tenure. Part IV looks to other branches of the federal government, the states, lower federal courts, and international jurisdictions to provide guidance for addressing the void in present law. Finally, Part V argues that an amendment to the United States Constitution is necessary to rid the Supreme Court of the ghosts that have haunted it since its inception. Part $\mathrm{V}$ also addresses the main counterarguments and alternatives. The amendment proposed in this Note specifically calls for compulsory retirement when a majority of the sitting Supreme Court Justices communicate to the Senate Judiciary Committee and the President, with a medical certificate or record, that a Justice is too incapacitated or impaired to remove him or herself from office and cannot faithfully perform his or her duties.

\section{CURRENT PROCEDURES FOR THE RETIREMENT OR REMOVAL OF A SUPREME COURT JUSTICE}

Article III, Section One of the United States Constitution provides that Justices of the Supreme Court "shall hold their Offices during good behavior." "Good behavior" was understood at the time of ratification to be the practical equivalent to life tenure and continues to have this meaning today. ${ }^{6}$ Therefore, Justices can leave the bench through death, retirement, or impeachment and removal.

The Constitution's directive for life tenure of members of the Supreme Court provides that upon death, a Justice's seat on the bench is vacated and the President then has the power to appoint a replacement. ${ }^{7}$ However, a Justice's retirement or resignation is purely a statutory animal; Chapter 17 of Title 28 of the United States Code supplies the procedure for the resignation or retirement of Justices and other federal judges. ${ }^{8}$

Resignation occurs when a Justice voluntarily relinquishes his or her office without meeting the requirements for retirement under 28 U.S.C. $\S \S 371-372 .{ }^{9}$ In contrast, Justices may voluntarily retire, "and be entitled to receive retirement compensation, in one of two ways - either by taking 'senior status' or by 'retiring from office" under 28 U.S.C. $§ 371 .{ }^{10}$ Commonly known as the "Rule of 80 ," beginning at age sixty-five and having served at least ten years, retiring Justices may receive retirement compensation if their age and judicial service total eighty

5. Id. art. III, $\S 1$.

6. Jonathan Turley, Good Behavior Clause, HeRITAge Found., https://www.heritage.org/ constitution/\#!/articles/3/essays/104/good-behavior-clause (last visited Nov. 8, 2020) [https:// perma.cc/8H7L-E5WU].

7. See U.S. Const. art. III, $\S 1 ; i d$. art. II, $\S 2$.

8. 28 U.S.C. $\S \S 371-377$ (2020).

9. Barry J. McMillion, Cong. Research Serv., R44235, Supreme Court Appointment Process: President's Selection of A Nominee 4 (2018); 28 U.S.C. $§ ~ 371-372$ (2020).

10. MCMillion, supra note 9, at 4 n.17; 28 U.S.C. $\S 371$ (2020). 
years. ${ }^{11}$ In its early days, many members of the Supreme Court were motivated to remain on the Court long after they likely should have in order to receive retirement benefits. ${ }^{12}$ The Judiciary Act of 1869, which gave Supreme Court Justices a full-salary pension, was passed by Congress to "encourage judges to retire rather than attempting to serve during extended periods of poor health and potential senility." "13

Interestingly enough, this statutory scheme also provides for retirement on the basis of disability. ${ }^{14}$ Section 372 states that "[a]ny justice . . . who becomes permanently disabled from performing his duties may retire from regular active service." 15 For lower federal court judges, subsection (b) even provides for involuntary retirement on the basis of disability. ${ }^{16}$ The judge's seat is then filled by the President if a certificate of disability is signed and the President believes that the "judge is unable to discharge efficiently all the duties of his office by reason of permanent mental or physical disability." ${ }^{\prime 17}$

Notably exempt from this subsection are Justices of the Supreme Court. ${ }^{18}$ If retiring under this section for permanent disability, Supreme Court Justices must voluntarily certify their own disability to the President in writing. ${ }^{19}$ Retirement for disability is a product of the Judicial Conduct and Disability Act of 1980 and is further discussed below in Part V of this Note. Although the Act was originally drafted to apply to Supreme Court Justices as well, concerns about the constitutionality of a statute that potentially limited terms of Supreme Court Justices prevented the Act from being passed as first written. ${ }^{20}$

With respect to the impeachment and removal of Supreme Court Justices, the House of Representatives has the ability to impeach, and the Senate has the power to remove with a two-thirds majority vote. ${ }^{21}$ Article II of the Constitution provides that "all civil Officers of the United States, shall be removed from office on Impeachment for, and Conviction of, Treason, Bribery, or other high Crimes and Misdemeanors." ${ }^{22}$ Impeachment of a Justice is extremely rare, and rarer still is removal. ${ }^{23}$ Due to the good behavior clause, "the impeachment power has

11. MCMillion, supra note 9, at 4 n.17.

12. See Robert Longley, US Supreme Court Retirement Benefits, ThoughtCo, https://www. thoughtco.com/us-supreme-court-retirement-benefits-3322414 (last updated Feb. 4, 2020) [https://perma.cc/NN6H-H9PW].

13. $I d$.

14. 28 U.S.C. $\S 372(2020)$.

15. Id. $\S 372(\mathrm{a})$.

16. Id. $\S 372(\mathrm{~b})$.

17. $I d$.

18. Id.

19. Id.

20. David J. Garrow, Mental Decrepitude on the U.S. Supreme Court: The Historical Case for a 28th Amendment, 67 U. CHI. L. REV. 995, 1062-65 (2000).

21. U.S. CONST. art. I, $\S \S 2-3$.

22. Id. art. II, $\S 4$.

23. Douglas Keith, Impeachment and Removal of Judges: An Explainer, BRENNAN CTR. FOR 
historically been limited to cases of serious ethical or criminal misconduct." ${ }^{24}$

The only Supreme Court Justice to face impeachment proceedings was Samuel Chase, who served from 1796 to $1811 .^{25}$ This single impeachment trial set an important precedent for subsequent impeachment and removal proceedings of Justices. Justice Chase's impeachment trial was ran by a DemocraticRepublican controlled House of Representatives, ${ }^{26}$ who strongly disagreed with Justice Chase's ardent and open support of the Federalist party. ${ }^{27}$ The Democratic-Republicans at the time believed that his behavior showed he lacked political objectivity on the bench and constituted "seditious intent" and judicial misconduct. ${ }^{28}$ However, Chase was acquitted when the Democratic-Republicans failed to obtain a two-thirds vote in the Senate. ${ }^{29}$ His acquittal helped define the independence of the Supreme Court and ultimately set the parameters for judicial impeachment - that no Supreme Court Justice could be removed simply because of his political beliefs. ${ }^{30}$

Although there remains critical debate over how the phrase "high Crimes and Misdemeanors" should be interpreted,$^{31}$ no serious reading of this clause could suffice as grounds to remove an incapacitated Justice from the Supreme Court. The same is true for lower federal court judges. There have been fifteen impeachments of federal judges in history, and the most common charges were "making false statements, favoritism toward litigants or special appointees, intoxication on the bench, and abuse of the contempt power." ${ }^{.32}$ Of these fifteen, only eight resulted in conviction in the Senate. ${ }^{33}$

JUST. (Mar. 23, 2018), https://www.brennancenter.org/our-work/analysis-opinion/impeachmentand-removal-judges-explainer [https://perma.cc/2V25-94HB].

24. Id.

25. Samuel Chase, OYEZ, https://www.oyez.org/justices/samuel_chase (last visited Sept. 27, 2020) [https://perma.cc/27DM-VH7T].

26. Party Divisions of the House of Representatives, 1789 to Present, U.S. HousE RePS.: Hist., ART \& ARChIVES, https://history.house.gov/Institution/Party-Divisions/Party-Divisions/ (last visited Sept. 27, 2020) [https://perma.cc/NM95-ULQ7].

27. Samuel Chase: The Samuel Chase Impeachment Trial, LAw LIBR. - AMER. L. \& LEGAL INFO., https://law.jrank.org/pages/5152/Chase-Samuel.html (last visited Sept. 23, 2020) [https:// perma.cc/DZZ5-3L55].

28. Id.; Samuel Chase Impeached, FED. JuD. CTR., https://www.fjc.gov/history/timeline/ samuel-chase-impeached (last visited Sept. 23, 2020) [https://perma.cc/Y6S2-X8SX].

29. Samuel Chase Impeached, supra note 28.

30. The Samuel Chase Impeachment Trial, supra note 27.

31. See generally Frank O. Bowman III, The Common Misconception About 'High Crimes and Misdemeanors,' ATLANTIC (Oct. 22, 2019), https:/www.theatlantic.com/ideas/archive/2019/ 10/what-does-high-crimes-and-misdemeanors-actually-mean/600343/ [https://perma.cc/2WWDM6MZ]; Madeleine Carlisle, What Are High Crimes and Misdemeanors? Here's the History, Time (Dec. 10, 2019), https://time.com/5745616/high-crimes-and-misdemeanors/ [https://perma.cc/ N4QF-2SDK].

32. Keith, supra note 23.

33. Id. 
Additionally, the failure to precisely follow the oaths of office Supreme Court Justices swear to does not constitute separate grounds for impeachment. Justices take two oaths of office before they are able to execute the duties of their office; in these, the person generally swears to uphold the Constitution and to impartially administer justice and all other duties of the position. ${ }^{34}$ The first oath, the Constitutional Oath, is established by Congress and today reads:

I, $\longrightarrow$ do solemnly swear (or affirm) that I will support and defend the Constitution of the United States against all enemies, foreign and domestic; that I will bear true faith and allegiance to the same; that I take this obligation freely, without any mental reservation or purpose of evasion; and that I will well and faithfully discharge the duties of the office on which I am about to enter. So help me God..$^{35}$

The second oath is the Judicial Oath and reads:

I, _ _ do solemnly swear (or affirm) that I will administer justice without respect to persons, and do equal right to the poor and to the rich, and that I will faithfully and impartially discharge and perform all the duties incumbent upon me as under the Constitution and laws of the United States. So help me God. ${ }^{36}$

Although the oaths are now codified, they are largely the product of formalistic traditions. ${ }^{37}$ The Constitutional Oath is taken by all federal employees except the President, and the Judicial Oath is taken by all federal judges. ${ }^{38}$ The Constitutional Oath is merely a formal prerequisite to compensation and a demonstration of legal acceptance of office. ${ }^{39}$ The Judicial Oath has been interpreted similarly and does not establish a substantive cause of action against judges for alleged violations of the oath. ${ }^{40}$ Neither oath of office taken by the Justices of the Supreme Court creates additional grounds for removal from the bench, especially and including when a Justice can no longer uphold the oaths due to incapacity.

Ultimately, the procedures in existence for impeachment and removal, retirement, or resignation all fall short. All are insufficient to address the crisis of a ghost Justice who is unable to voluntarily remove him or herself from the bench. As Parts II and III below demonstrate, this crisis is all too inevitable, and failing to proactively devise a solution is extremely dangerous for the future of

34. Oaths of Office, SuP. CT. U.S., https://www.supremecourt.gov/about/oath/oathsofoffice. aspx (last visited Sept. 27, 2020) [https://perma.cc/UD2X-GDKN].

35. 5 U.S.C. $\S 1331$ (2020).

36. 28 U.S.C. $\S 453$ (2020).

37. Term of Judicial Salaries, 7 Op. Att'y Gen. 303, 303, 310 (1856); Major W.F. Smith, 19 Op. Att'y Gen. 283, 284 (1891); Lewis v. Green, 629 F. Supp. 546, 554 (D.D.C. 1986).

38. Oaths of Office, supra note 34.

39. Term of Judicial Salaries, 7 Op. Att'y Gen. at 303, 310; Major W.F. Smith, 19 Op. Att'y Gen. at 284.

40. Lewis, 629 F. Supp. at 554. 
the highest court in the United States as well as for the administration of justice in general.

\section{GHOSTS OF THE PAST: THE HISTORICAL CASE}

\section{A. 1789 to the $20^{\text {th }}$ Century}

One of the original members of the first United States Supreme Court begins the historical inquiry of incapacitation on the bench. Justice William Cushing was nominated to the first Supreme Court in $1789 .{ }^{41}$ Cushing was nominated as the Chief Justice in 1795, but citing ill health, he stepped down after a week. ${ }^{42} \mathrm{He}$ thereafter remained an Associate Justice. ${ }^{43}$ Commenting on his poor condition, a New Hampshire Senator wrote in a letter that, "[t]ime, the enemy of man, has much impaired his mental faculties." ${ }^{\text {44 }}$ Justice Cushing was forced to remain on the bench until his death at the age of seventy-eight in 1810, relying on the Supreme Court's salary to survive, and he was posthumously characterized as "incompetent" by a fellow Associate Justice. ${ }^{45}$

Few historical records detail Justice Henry Baldwin's precise physical and mental state, but his tenure is described as a "case of clear mental incompetence." ${ }^{46}$ Before he was nominated by President Andrew Jackson in 1830, Baldwin's last term in the House of Representatives was cut short when he resigned due to illness. ${ }^{47}$ Explanations of his lackluster service on the bench range from insanity to a peculiar sense of humor, and a colleague of his on the Supreme Court described him as "partially deranged at all times." Justice Baldwin was eventually hospitalized for "incurable lunacy," and he missed all of the 1833 term. ${ }^{49}$ Justice Baldwin nevertheless returned to the Court and remained a member for eleven more years until he died in $1844 .{ }^{50}$ There is no evidence to

41. Cushing, William, FED. JUD. CTR., https://www.fjc.gov/history/judges/cushing-william (last visited Sept. 27, 2020) [https://perma.cc/66YT-TET4].

42. William Cushing, OYEZ, https://www.oyez.org/justices/william_cushing (last visited Sept. 27, 2020) [https://perma.cc/4QSN-RCCB].

43. Id.

44. Cushing, William, Biographical EnCyClopedia of the Supreme Court 151 (Melvin I. Urofsky ed., 2006), https://library.cqpress.com/scc/document.php?id=bioenc-427-18166979174\&v=cc86c5b610618229 (last visited Sept. 26, 2020) [https://perma.cc/7Y7U-U2V3].

45. Id.

46. Garrow, supra note 20, at 1001.

47. Baldwin, Henry, Biographical Encyclopedia of the Supreme Court 7 (Melvin I. Urofsky ed., 2006), https://library.cqpress.com/scc/document.php?id=bioenc-427-18975-1014108 $\& \mathrm{v}=6887 \mathrm{f7307b0f4ffd \#} \mathrm{(last} \mathrm{visited} \mathrm{Sept.} \mathrm{27,} \mathrm{2020)} \mathrm{[https://perma.cc/29YS-QEL8].}$

48. Garrow, supra note 20, at 1002.

49. Id.

50. Henry Baldwin, OYEZ, https://www.oyez.org/justices/henry_baldwin (last visited Sept. 27, 2020) [https://perma.cc/XQ8B-ZGKB]. 
indicate Justice Baldwin was encouraged to retire, ${ }^{51}$ but one wonders what efforts may have been made if there was an adequate solution.

Replacing Justice Baldwin was Justice Robert C. Grier, confirmed in $1846 .{ }^{52}$ Justice Grier was rendered partially paralyzed after a series of strokes in 1867 , from which he never fully recovered. ${ }^{53}$ Despite serious physical and mental incapacities, Justice Grier remained on the bench until he finally retired nearly three years later. ${ }^{54}$

During a conference in which the Court met to discuss two connected cases, one being the significant Hepburn v. Griswold, Grier's mental incapacity was clearly indicated to the Court. ${ }^{55}$ His colleagues were forced to remind him that the argument he was making for the second case was entirely inconsistent with his vote in the former. ${ }^{56}$ Grier subsequently changed his vote in Hepburn, providing the swing vote needed for a five-member majority. ${ }^{57}$ Following Justice Grier's embarrassing behavior during conference, all of his colleagues agreed that action needed to be taken.$^{58} \mathrm{He}$ finally heeded the advice of his colleagues and retired in January of $1870 . .^{59}$ Less than a year later, Justice Grier died at the age of seventy-six. ${ }^{60}$ The Hepburn decision, with Grier as a member of the majority, was not handed down until after Grier had retired on February 7, 1870. ${ }^{61}$ Allowing a "confused mind" to declare an Act of Congress unconstitutional led to intense criticism of that decision, and it was promptly overturned. ${ }^{62}$

Justice Nathan Clifford joined the Court in 1858 and served for approximately fifteen years before his competency was called into question. ${ }^{63} \mathrm{In}$ 1877, a decline in mental capacity was apparent, with his colleague Justice Samuel F. Miller even going so far as to say his "mental failure is obvious to all the Court." ${ }^{\prime 4}$ In one instance, Justice Clifford rejected an assignment of authoring a majority opinion, forgetting that he had voted for the majority. ${ }^{65}$ In 1880 , Clifford suffered a stroke which ended any active participation he may have still

51. Garrow, supra note 20, at 1003.

52. Robert Cooper Grier (1794-1870), Dick. C. ARChives \& Special Collections (2005), http://archives.dickinson.edu/people/robert-cooper-grier-1794-1870 [https://perma.cc/B2TJFLCM].

53. Id.

54. Id.

55. Garrow, supra note 20, at 1003-04.

56. Id. at 1004.

57. Id.

58. Id.

59. Robert C. Grier, OYEZ, https://www.oyez.org/justices/robert_c_grier (last visited Sept. 27, 2020) [https://perma.cc/2AGX-9UZ2]; Robert Cooper Grier (1794-1870), supra note 52.

60. Id.

61. See generally Hepburn v. Griswold, 75 U.S. 603 (1870).

62. Garrow, supra note 20, at 1005; Legal Tender Cases, 79 U.S. 457 (1871).

63. Garrow, supra note 20, at 1006.

64. Id.

65. Id. 
had on the Court. ${ }^{66}$ Refusing to resign, Clifford haunted the Supreme Court as a ghost Justice for a full term before he died while still in office in $1881 .{ }^{67}$

During the same period that Justice Clifford's mental capacity was preventing him from participating, Justice Ward Hunt, then only sixty-nine years old, also suffered a stroke. ${ }^{68} \mathrm{He}$ "was struck speechless with paralysis," and his participation on the Court all but ended. ${ }^{69} \mathrm{He}$ remained on the Court for a breathtaking three more years ${ }^{70}$ until Congress passed a special bill providing for an exception to the requirement that a Justice serve for a full ten years and be a minimum age of seventy before they are eligible for a full pension. ${ }^{71}$ Most problematic is the fact that the incapacities of Justice Hunt and Justice Clifford persisted concurrently for four years, affecting the outcomes of countless decisions. ${ }^{72}$

The last mental incapacity crisis on the Supreme Court of this era involved Justice Stephen J. Field. Justice Field noticeably struggled with his judicial duties, and there is evidence that his colleagues often "coached" him on the cases before them. ${ }^{73}$ After Chief Justice Melville Weston Fuller unsuccessfully attempted to persuade Justice Field to retire, it was decided that no further majority opinions would be assigned to Field. ${ }^{74}$ Field remained on the bench a full twenty months after he last authored a majority opinion. ${ }^{75}$

\section{B. The $20^{\text {th }}$ Century to Present}

Beginning the next century of incapacity on the Supreme Court is Justice Joseph McKenna. Justice McKenna was confirmed to the Supreme Court in 1898 and served for twenty-six years. ${ }^{76}$ The end of his career on the bench is rife with powerful evidence that McKenna had become too mentally incapacitated to adequately participate on the bench. ${ }^{77}$ Chief Justice William Howard Taft recounted in a confidential memorandum the details of Justice McKenna's performance and of a meeting he had with the rest of the members of the Court

66. Clifford, Nathan, Biographical Encyclopedia of the Supreme Court 145 (Melvin I. Urofsky ed., 2006), https://ibrary.cqpress.com/scc/document.php?id=bioenc-427-18166979162\&v=140caa9b2ec145c5\# [https://perma.cc/M7KW-BV8U].

67. Id.

68. Ward Hunt, OYEZ, https://www.oyez.org/justices/ward_hunt (last visited Sept. 27, 2020) [https://perma.cc/7FJL-QKWS].

69. Garrow, supra note 20, at 1007.

70. Ward Hunt, supra note 68.

71. Garrow, supra note 20, at 1007; see also Act of Jan. 27, 1882, ch. 4, 22 Stat. 2.

72. Garrow, supra note 20, at 1007-08.

73. Id. at 1008 .

74. Id. at 1009.

75. Id.; see Telfener v. Russ, 163 U.S. 100 (1896).

76. Joseph McKenna, 1898-1925, SUP. CT. HIST. Soc'Y, https://supremecourthistory. org/timeline_mckenna.html\# (last visited Sept. 27, 2020) [https://perma.cc/VD57-MPRT].

77. Garrow, supra note 20, at 1014-15. 
about him. ${ }^{78}$ Prior to the meeting, Chief Justice Taft and Associate Justice Willis Van Devanter consulted McKenna's doctor who emphatically recommended retirement for McKenna. ${ }^{79}$

Most telling however, is Chief Justice Taft's account of what he and the seven other Justices of the Court agreed to do about McKenna ${ }^{80}$ Taft stated, "[I]t seemed to me unwise for us to decide any case in which there were four on one side and four on the other, with Mr. Justice McKenna's casting the deciding vote." ${ }^{\text {"11 }}$ All of the Justices emphasized to Taft "the necessity for doing this which seemed to be our duty," and therefore, the Supreme Court refused to decide any case where Justice McKenna would be the deciding vote. ${ }^{82}$ Justice McKenna finally acquiesced and retired a few months later in January of $1925 .{ }^{83}$

Even the Great Dissenter, Justice Oliver Wendell Holmes, was not immune to the effects that great age can unfortunately have on the mind. At nearly ninety years old, Justice Holmes was seen dozing at the bench and during conferences. ${ }^{84}$ While Justice Holmes is considered to be "one of America's greatest justices," 85 the end of his career is indistinguishable from others who were also explicitly asked to retire. ${ }^{86}$ Justice Oliver Wendell Holmes remains the oldest Justice to have served on the Supreme Court. ${ }^{87}$

Perhaps one of the most woeful illustrations of mental difficulties on the bench is that of Justice Charles E. Whittaker. He is often characterized as "one of the worst justices [sic] appointed to the Supreme Court in the twentieth century." ${ }^{88}$ Justice Whittaker has been criticized for the inconsistency with which he cast votes, ${ }^{89}$ and some of his colleagues seemed to have taken advantage of his famous indecisiveness. ${ }^{90}$ Justice Whittaker was often subjected to intense

78. Id. at 1015; see also Walter F. Murphy \& C. Herman Pritchett, Courts, Judges, and Politics: An Introduction to the Judicial Process 217-19 (2d ed. 1974).

79. MurPhy \& PRITCHETT, supra note 78 , at 217-18.

80. Id. at 218 .

81. Id.

82. Id.

83. Garrow, supra note 20, at 1016.

84. Id. at 1017.

85. John Fox, Oliver Wendell Holmes, THIRTEEN, https://www.thirteen.org/wnet/ supremecourt/capitalism/robes_holmes.html (last visited Sept. 27, 2020) [https://perma.cc/6D7Q8WUZ].

86. Garrow, supra note 20, at 1018.

87. FAQs - Supreme Court Justices, Sup. CT. U.S., https://www.supremecourt.gov/ about/faq justices.aspx (last visited Sept. 27, 2020) [https://perma.cc/28HU-FW95].

88. Craig Alan Smith, Failing Justice: Charles Evan Whittaker on the Supreme COURT 177 (2005).

89. Id. at 178 .

90. Id. at 194-96; see also More Perfect: The Political Thicket, WNYC STUdIOs (June 10, 2016), https://www.wnycstudios.org/podcasts/radiolabmoreperfect/episodes/the-political-thicket [https://perma.cc/62H3-VSSF] (podcast discussing the Supreme Court's entrance into the political thicket with a redistricting case). 
lobbying by his colleagues in order to sway his vote one way or the other, and as a man already suffering from recurrent depression and anxiety, one is not entirely surprised to find out that Justice Whittaker's tenure on the bench ended in a complete physical and emotional breakdown..$^{91}$ By the middle of his last term, Whittaker even considered suicide multiple times. ${ }^{92}$

The turning point of his final term was the Court's notorious entrance into the "political thicket" in Baker v. Carr. ${ }^{33}$ Whittaker appeared to be the deciding vote in a deadlocked Court, and Justice Felix Frankfurter even lectured him for hours in his chambers on how Frankfurter thought Whittaker should vote. ${ }^{94}$ By February of 1962, Justice Whittaker's involvement on the Court necessarily ceased due to his poor mental and emotional health. ${ }^{95}$ Justices John Marshall Harlan and Hugo Black decided at the time to hold over any necessary re-arguments in cases where Whittaker would cast the deciding vote because they doubted his ability to make rational decisions. ${ }^{96}$

After what became his final day on the Court in March 1962, Justice Whittaker was admitted into a Washington, D.C. hospital where he remained for several weeks. ${ }^{97}$ Chief Justice Earl Warren visited him there and immediately determined that Whittaker must retire on grounds of disability. ${ }^{98}$ A panel of military physicians ultimately certified that Whittaker suffered from a "permanent" disability, and recommended that he retire. ${ }^{99}$ Whittaker conceded and drafted a letter informing President John F. Kennedy of his retirement. ${ }^{100}$

The story of Justice Whittaker's "five-year tenure" 101 on the bench raises a number of "what if" questions. Federal law requires that a judge retiring on the basis of disability must personally certify to the President the disability in writing. ${ }^{102}$ What if Justice Whittaker, due to his complete physical and emotional breakdown, was unable to certify his disability in writing to President Kennedy? Even further, but not impossible to imagine, what if Whittaker had unsuccessfully attempted suicide and remained alive in a vegetative state while the recommendations to retire fell on deaf ears?

Holding the record for longest time served on the Supreme Court is Justice William O. Douglas, serving for nearly four decades. ${ }^{103}$ During a New Year's Day

91. Sмiтh, supra note 88 , at 178.

92. Id. at 205 .

93. Id.; see also More Perfect: The Political Thicket, supra note 90; see also Baker v. Carr, 369 U.S. 186 (1962).

94. SMITH, supra note 88, at 212.

95. Id. at 215.

96. Id. at 217.

97. Id. at 219.

98. Garrow, supra note 20, at 1049.

99. Id. at 1049 .

100. Smith, supra note 88, at 222 .

101. Id. at 109 .

102. 28 U.S.C. $\S 372(a)(2020)$.

103. William O. Douglas, OYEZ, https://www.oyez.org/justices/william_o_douglas (last visited 
vacation in 1974, Douglas suffered a severe stroke, leaving him partially paralyzed. ${ }^{104}$ During his stay at the hospital, he succumbed to paranoia, believing the treatments he was receiving were torture by his far-right enemies. ${ }^{105}$ Justice Douglas was absent from the bench for nearly three months, and when he returned, he had visibly deteriorated. ${ }^{106}$ Remaining paranoid, Douglas ordered his staff to hide his medical reports from the rest of the bench in an effort to conceal his diminishing abilities..$^{107}$

His colleagues nonetheless came to an agreement not to accept any cases where Douglas's vote would be determinative, or to even issue any opinions in close cases. ${ }^{108}$ From this point forward, Justice Douglas was a ghost upon the bench. He was physically present but provided no meaningful contribution. At the end of his career, Douglas was confined to a wheelchair and had to be carried in and out of rooms and buildings, his speech was slurred, and his family and friends begged him to retire. ${ }^{109}$ On November 12, 1975, Justice Douglas finally gave up the fight, and poignantly wrote his resignation letter with his one good hand during the last oral argument of his career. ${ }^{110}$

Justice Thurgood Marshall, the first African American Justice on the Supreme Court and one of the most celebrated judicial champions of civil rights, also had an unfortunate end to his famous tenure on the Court. While Marshall was often thought of as generally unhealthy, ${ }^{111}$ his career ended with additional concerns about his mental health. ${ }^{112}$ Some thought that Justice Marshall "often seemed uninformed and disengaged," and that he simply followed Justice William J. Brennan's lead. ${ }^{13}$ After over twenty years on the bench, Marshall publicly criticized the most recent Supreme Court appointment, Justice David Souter, and the President who appointed him, President George H.W. Bush. ${ }^{114}$ Many of Marshall's closest friends and longtime supporters found this behavior embarrassing. ${ }^{115}$

In another uncomfortable public display of his declining faculties, Marshall became confused and unsure of what position a party was arguing for during an

Sept. 27, 2020) [https://perma.cc/28JK-D4C8].

104. Bruce Allen Murphy, Wild Bill: The Legend and Life of William O. Douglas 481-82 (2003).

105. Id. at 483.

106. Garrow, supra note 20, at 1052.

107. MuRPHY, supra note 104, at 487.

108. Id. at 487-88.

109. Id. at 489-92.

110. Id. at 494.

111. Philip M. Boffey, Health of Justices Poses Little Threat to High Court, N.Y. TimES (Sept. 20, 1987), https://www.nytimes.com/1987/09/20/us/health-of-justices-poses-little-threat-to-highcourt.html [https://perma.cc/66VL-LL5T].

112. Juan Williams, Thurgood Marshall: American Revolutionary 390 (1998).

113. Garrow, supra note 20, at 1072.

114. WiLliams, supra note 112 , at 390.

115. Id. 
oral argument while he was questioning one of the litigants. ${ }^{116}$ At the end of his career, Marshall had difficulty hearing and reading, and he walked with a cane. ${ }^{117}$ During the final conference of the summer 1991 term, Marshall informed the other members of the Court that he was retiring. ${ }^{18}$ Less than two years later, Thurgood Marshall died of heart failure. ${ }^{119}$ Yet his mental capacity remained a topic of debate even after his death, and researchers were quick to review his case files that were made available following his death. ${ }^{120}$

Chief Justice William H. Rehnquist is the third most recent death of an active Justice on the Supreme Court. Chief Justice Rehnquist was sworn into the Supreme Court on January 7, 1972, as an Associate Justice, and was later promoted to Chief Justice in 1986. ${ }^{121}$ In an intimate and moving biography by Rehnquist's close friend from his final nineteen years of life, the Chief Justice is described in his last year of life as "an invalid who could no longer eat food normally and constantly wiped spittle from his tracheotomy tube." ${ }^{122}$ During this last year, the Chief Justice continued to work from his home, confined to a wheelchair-accessible basement. ${ }^{123}$

Rehnquist fought extremely hard against thyroid cancer. ${ }^{124} \mathrm{He}$ was even expected to have his tracheotomy tube removed and had plans to return to the Court. ${ }^{125}$ However, the Chief Justice died on September 3, 2005. ${ }^{126}$ No justifiable concerns or allegations have been made posthumously that Rehnquist was too much of an "invalid" to contribute to the Supreme Court. However, Rehnquist kept most details of his thyroid cancer private, and he gave no information on the extent of the chemotherapy he received. ${ }^{127}$ One cannot help but wonder if the chemotherapy treatments and confinement to his basement had a detrimental effect on his ability to adequately serve the Court during his final year as Chief Justice.

The historical inquiry of incapacity on the highest court in the land ends with the recent passing of Justice Ruth Bader Ginsburg on September 17, 2020, at the

116. Garrow, supra note 20, at 1072-74.

117. WiLliams, supra note 112 , at 390.

118. Id.

119. Thurgood Marshall, OYEZ, https://www.oyez.org/justices/thurgood_marshall (last visited Nov. 8, 2020) [https://perma.cc/X4TL-NHAQ].

120. Garrow, supra note 20, at 1076.

121. William Hubbs Rehnquist (1924-2005), LEGAL INFO. INST., https://www.law.cornell.edu/ supct/justices/rehnquist.bio.html (last visited Nov. 8, 2020) [https://perma.cc/5KK7-54A2].

122. Herman J. Obermayer, Rehnquist: A Personal Portrait of the Distinguished Chief Justice of the U.S. at xiii (2009).

123. Id. at 217.

124. Id. at 227 .

125. Id.

126. $I d$. at 229 .

127. Linda Greenhouse, Chief Justice Rehnquist Dies at 80, N.Y. Times (Sept. 4, 2005), https://www.nytimes.com/2005/09/04/politics/chief-justice-rehnquist-dies-at-80.html [https://perma.cc/9VVF-3JZD]. 
age of eighty-seven. ${ }^{128}$ Born in 1933, Justice Ginsburg, a champion for gender equality, was often asked about her age, health, and ability to perform on the bench prior to her death. ${ }^{129}$ Opponents of Ginsburg and those that had a stake in the next Supreme Court confirmation battle often pointed to her advanced age and the multiple bouts of cancer Ginsburg battled as evidence that she was incapable to serve on the bench. ${ }^{130}$ In defense of Ginsburg, she was still extremely active; there was no indication that her battles with cancer ever affected her mental capabilities; and until the 2018 term, she had never missed a day of oral arguments. ${ }^{131}$

Moving on from the past to the current Supreme Court, the members of the bench are reaching great ages. Three of the nine Justices are seventy or older: Justice Stephen Breyer is currently eighty-two years old and has served on the bench for twenty-six years ${ }^{132}$; Justice Clarence Thomas succeeded Justice Marshall in 1991, and he is now seventy-two years old ${ }^{133}$; and Justice Samuel Alito turned seventy in April of 2020. ${ }^{134}$ Because retirement from the Supreme Court is arguably often motivated by political concerns, people will frequently speculate on future retirements, but it is unclear when or if any of the current members of the Supreme Court plan on retiring. ${ }^{135}$

The vast history of incapacity on the Supreme Court provides many real-life examples that demand a future resolution. These examples make it clear that severe incapacity on the bench has occurred often enough to reasonably believe that cases of severe incapacity will indeed occur again. Proactively devising a solution now will better serve the Supreme Court and the nation when an incapacity crisis inevitably strikes again.

128. Nina Totenberg, Justice Ruth Bader Ginsburg, Champion of Gender Equality, Dies at 87, NPR (Sept. 18, 2020), https://www.npr.org/2020/09/18/100306972/justice-ruth-bader-ginsburgchampion-of-gender-equality-dies-at-87 [https://perma.cc/87C2-UYMQ].

129. Ruth Bader Ginsburg, OYEZ, https://www.oyez.org/justices/ruth_bader_ginsburg (last visited Nov. 8, 2020) [https://perma.cc/FE2D-WUD8]; Joan Biskupic, Justice Ginsburg Declares Her Good Health, but High-Stakes Scrutiny Persists, CNN, https://www.cnn.com/2019/10/03/ politics/rbg-health-supreme-court-lists/index.html (last updated Oct. 3, 2019) [https://perma. cc/4YCH-NLBM]; Nina Totenberg, Justice Ginsburg: 'I Am Very Much Alive', NPR (July 24, 2019), https:/www.npr.org/2019/07/24/744633713/justice-ginsburg-i-am-very-much-alive [https:// perma.cc/6EK7-5BMW] [hereinafter Totenberg, 'Very Much Alive'].

130. Totenberg, 'Very Much Alive', supra note 129.

131. Ruth Bader Ginsburg, OYEZ, supra note 129.

132. Stephen G. Breyer, OYEZ, https://www.oyez.org/justices/stephen_g_breyer (last visited Dec. 21, 2020) [https://perma.cc/GB9E-92GR].

133. Clarence Thomas, OYEZ, https://www.oyez.org/justices/clarence_thomas (last visited Dec. 21, 2020) [https://perma.cc/HUF8-JY2R].

134. Samuel A. Alito, Jr., OYEZ, https://www.oyez.org/justices/samuel_a_alito_jr (last visited Dec. 21, 2020) [https://perma.cc/W2N9-GLKU].

135. Kayla M. Joyce, The Retirement Strategy of Supreme Court Justices: An Economic Approach, HonORS SchOlAR THESES 2 (2017). 


\section{THE INEVITABILITY OF FUTURE GHOSTS: THE MEDICAL CASE}

As the number of older persons in the population continues to grow rapidly, society is acutely aware of age-related impairments and disabilities. While the effects of aging are highly circumstantial and individual, age "is associated with increased prevalence of disease conditions." ${ }^{\prime 36}$ Some of these age-related diseases are "cardiovascular disease, cancer, arthritis, dementia, cataract, osteoporosis, diabetes, hypertension and Alzheimer's disease."137 "The incidence of all of these diseases increases rapidly with aging [and] increases exponentially with age, in the case of cancer."138 Additionally, "[t]he chance of having a stroke about doubles every 10 years after age 55."139

Generally, life expectancy is increasing in western countries like the United States. ${ }^{140}$ In 2000 , life expectancy for the total United States population was 76.8. ${ }^{141}$ In 2018 , life expectancy increased to 78.7 years. ${ }^{142}$ Life expectancy and increased risk of disease are concomitant - as people live longer, they will also experience more disease. ${ }^{143}$ As mentioned earlier, one of the nine Justices on the current Supreme Court is well above the country's life expectancy. ${ }^{144}$ Based on the increased risk of disease associated with advanced age, there is a serious cause for concern for the lack of a solution in the event a Justice suffers from one of these debilitating diseases and, consequently, is unwilling or unable to remove him or herself from the bench.

Focusing on the mental health of the aging population, dementia and depression are the most common mental health problems among people over sixty. ${ }^{145}$ Dementia is a general term that refers to several diseases and conditions that result in a decline in "memory, language, problem-solving, and other

136. Todd Manini, Development of Physical Disability in Older Adults, NAT'L CTR. FOR BIOTECH. INFO. at 4 (Dec. 2011), https://www.ncbi.nlm.nih.gov/pmc/articles/PMC3868456/ pdf/nihms535356.pdf [https://perma.cc/252K-4AWK].

137. Aging: Associated Condition, Diseases and Information, DisABLED WorLD, https://www. disabled-world.com/health/aging/ (last updated Mar. 27, 2020) [https://perma.cc/PK9D-TELX] [hereinafter Aging].

138. Id.

139. Stroke: Family History, Ctrs. For Disease Control \& PreVention, https://www.cdc. gov/stroke/family_history.htm (last visited Nov. 7, 2020) [https://perma.cc/5QDR-84WY].

140. Aging, supra note 137.

141. Health, United States, 2010, CTrs. For Disease Control \& Prevention at 134 (2010), https://www.cdc.gov/nchs/data/hus/2010/022.pdf [https://perma.cc/UF8H-EWH9].

142. Jiaquan Xu et al., Mortality in the United States, 2018, Ctrs. For Disease Control \& PREVENTION at 1 (Jan. 2020), https://www.cdc.gov/nchs/data/databriefs/db355-h.pdf[https://perma. cc/WF3B-3M5Y].

143. Aging, supra note 137.

144. See supra Part II.B.

145. Mental Health of Older Adults, World Health ORG. (Dec. 12, 2017), https://www.who. int/news-room/fact-sheets/detail/mental-health-of-older-adults [https://perma.cc/NVU5-2ZL6]. 
thinking abilities." ${ }^{\text {146 }}$ Although depression at any age results in similar symptoms, geriatric depression can worsen or complicate existing age-related health problems. ${ }^{147}$ Other common chronic conditions, of which $60 \%$ of older adults managed two or more, include heart disease, cancer, emphysema, stroke, and diabetes mellitus. ${ }^{148}$

Alzheimer's disease is the most common form of dementia, accounting for $60-80 \%$ of dementia cases. ${ }^{149}$ According to the National Institute on Aging, "more than 5.5 million Americans, most of them age 65 or older, may have dementia caused by Alzheimer's."150 According to the Alzheimer's Association, "[o]ne in 10 people . . . age 65 and older" suffers from Alzheimer's, and the percentage of people suffering from the terminal disease only increases with age. ${ }^{151}$ In 2018, $16 \%$ of people between the ages of sixty-five and seventy-four had Alzheimer's dementia, and $44 \%$ of people between seventy-five and eighty-four had the disease. ${ }^{152}$ Other population-based studies have estimated that $14 \%$ of people age seventy-one and older have some form of dementia. ${ }^{153}$ For a point of reference, the average age at retirement for Supreme Court Justices after the year 1900 is 73.6. ${ }^{154}$

Not only does depression tend to occur at increasing rates with age, it "can lead to impairments in physical, mental, and social functioning." ${ }^{155}$ Compounding the problem, American lawyers suffer from depression "at a rate twice that (20\%) of the general population." "156 No empirical studies have been performed on the

146. What Is Dementia?, ALZHEIMER's Ass'N, https://www.alz.org/alzheimers-dementia/whatis-dementia (last visited Sept. 27, 2020) [https://perma.cc/6T3Q-EZDT].

147. Brian Krans, Geriatric Depression (Depression in Older Adults), Healthline, https://www.healthline.com/health/depression/elderly (last updated June 22, 2017) [https://perma. cc/8XS9-JHLZ].

148. Older Adults, Off. Disease Prevention \& Health Promotion, https://www. healthypeople.gov/2020/topics-objectives/topic/older-adults (last visited Sept. 27, 2020) [https://perma.cc/3GX4-TN6U].

149. What Is Dementia?, supra note 146.

150. Alzheimer's Disease Fact Sheet, NAT'L InST. ON AGING, https://www.nia.nih.gov/ health/alzheimers-disease-fact-sheet (last updated May 22, 2019) [https://perma.cc/VEA3-KRHN].

151. 2018 Alzheimer's Disease Facts and Figures, AlzHEIMER's Ass'N at 17 (2018), https://www.alz.org/media/homeoffice/facts $\% 20$ and $\% 20$ figures/facts-and-figures.pdf [https://perma.cc/4UQD-6APH].

152. Id.

153. Id.

154. Adam Feldman, Empirical SCOTUS: Retirement Plan Blues, SCOTUSBLOG (May 23, 2018, 1:19 PM), https:/www.scotusblog.com/2018/05/empirical-scotus-retirement-plan-blues/ [https://perma.cc/T2PG-YFPR].

155. The State of Mental Health and Aging in America Issue Brief \#1: What Do the Data Tell Us?, Ctrs. For Disease Control \& Prevention \& Nat'L Ass'N of Chronic Disease Dirs. at 2 (2008), https://www.cdc.gov/aging/pdf/mental_health.pdf [https://perma.cc/H5Z2-LJSF].

156. Dan Lukasik, Judges Struggling with Depression: More Common Than You Think, LAWYERS WITH DEPRESSION (Feb. 15, 2015), http://www.lawyerswithdepression.com/articles/ 
rate that American judges suffer from depression. ${ }^{157}$ However, in 2018, Australia performed the country's first survey measuring judicial stress and wellbeing. ${ }^{158}$ Data compiled from the survey indicated that Australia's judges suffer from depression at about the same rate as the general population, but psychological distress was identified as a prominent and common problem among Australia's judges. ${ }^{159}$ Noting that no "individual . . . can sustain elevated and increasing stress indefinitely, without showing signs of strain and impaired functioning," the survey's report states that the findings "indicate[] a simmering occupational health and safety concern that demands attention."160

Perhaps the most persuasive medical occurrence justifying a remedy for the ghosts haunting the Supreme Court is one that has yet to occur but is not difficult to imagine. Although a person can enter a coma for many different reasons, one reason is a stroke, which is a common age-related problem. ${ }^{161}$ Recovery from a coma caused by a stroke "carries the worst prognosis of all." ${ }^{162}$ The macabre thought of a Justice remaining on the bench while in a persistent vegetative state calls for direct attention to the void within constitutional and statutory law.

Further intensifying any adverse effects from medical issues, age-related or not, is the notoriously heavy workload of the Supreme Court. In 2019, the Supreme Court considered 6,581 petitions for review. ${ }^{163}$ In a typical year, 7,000 to 8,000 petitions for certiorari are filed. ${ }^{164}$ The Supreme Court Historical Society notes an "almost fivefold increase in work" between the 1940-1941 term and the end of the 2015 term. ${ }^{165}$ The American Bar Foundation determined in the 1970s that the "sharp [increase in] absolute growth in the [Court's] caseload . . . [is] a source of serious concern about the Supreme Court's ability to discharge its duties." 166 Prior Justices have themselves raised concerns about the Court's

judges-struggling-depression-common-think/ [https://perma.cc/G62K-U5VJ].

157. Id.

158. Carly Schrever, Australia's First Research Measuring Judicial Stress and Wellbeing: A Preview of the Findings, 92 AustL. L.J. 859, 862 (2018).

159. Id.

160. Id.

161. Coma: Symptoms \& Causes, MAYo ClinIC (Sept. 12, 2018), https://www.mayoclinic. org/diseases-conditions/coma/symptoms-causes/syc-20371099 [https://perma.cc/PAC3-SR5V]; Older Adults, supra note 148.

162. David Bates, The Prognosis of Medical Coma, 71 J. Neurology, Neurosurgery \& PSYCHIATRY at i20, i21 (2001).

163. The Supreme Court - The Statistics, 133 HARv. L. REv. 412, 420 (2019).

164. Supreme Court Procedure, SCOTUSBLOG, https://www.scotusblog.com/reference/ educational-resources/supreme-court-procedure/ (last visited Nov. 8, 2020) [https://perma.cc/L7H9HFGE].

165. How the Court Works | The Court's Workload and Staff, Sup. Ст. Hist. Soc'y, https:// supremecourthistory.org/htcw_workload.html (last visited Sept. 27, 2020) [https://perma.cc/M2EU$4 \mathrm{~K} 3 \mathrm{Y}]$.

166. Gerhard Casper \& Richard A. Posner, The Workload of the Supreme Court 6-7 (1976). 
workload. Justice Brennan published an article on the Supreme Court's workload, stating in agreement with Justices Byron White and John Paul Stevens, that "the Supreme Court confronts a calendar crisis so severe as to threaten the Court's ability effectively to discharge its vital responsibility."167

This is not to say that because members of the Supreme Court are typically older, they are inherently unable to perform their job duties or handle their immense workload once they reach a particular age. The medical case for a resolution of the gap in the law is only to call attention to the probability with which past, present, and future Justices of the Supreme Court will struggle with ailments naturally concomitant with aging. Supreme Court Justices may sit on the highest court in the land, but they are unfortunately not above the mortality with which all of humanity is confronted.

\section{A JURISDICTIONAL OVERVIEW}

\section{A. The $25^{\text {th }}$ Amendment to the Constitution}

Presidential succession was first addressed at the 1787 Constitutional Convention, but the convention ended with no clear answer as to how unexpected vacancies would be filled. ${ }^{168}$ Subsequent controversies regarding vacancies in the Executive office prompted later discussion on the issue. These controversies include President John Tyler's ascension to presidency after President William Henry Harrison's death in 1841, the vacancy created when President Garfield was assassinated in 1881, President Woodrow Wilson's inability to discharge his duties following a stroke, and the death of President Franklin D. Roosevelt in $1945 .^{169}$

The most powerful event that ultimately led to the proposal and ratification of the Twenty-Fifth Amendment was the assassination of President John F. Kennedy. ${ }^{170}$ The action was driven "by the sense at that time that, if Kennedy had lived, the country would have had to deal with the problem of presidential inability in a most tragic setting." ${ }^{171}$ The proposed amendment was approved by both houses of Congress in 1965 and was quickly ratified by the necessary thirtyeight states by $1967 .{ }^{172}$

The Twenty-Fifth Amendment details who succeeds a vacancy in the offices of President or Vice President, the authority of the President to declare that he is unable to serve, and most importantly, gives authority to others to declare that the

167. William J. Brennan, Jr., Some Thoughts on the Supreme Court's Workload, 66 JUDiCATURE 230, 230 (1983).

168. John D. Feerick, The Twenty-Fifth Amendment: An Explanation and Defense, 30 WAKE Forest L. REV. 481, 483-84 (1995).

169. Id. at $484-88$.

170. Id. at 494.

171. Id.

172. Id. at 497. 
President is unable to serve. ${ }^{173}$ Specifically, Section Four provides:

Whenever the Vice President and a majority of either the principal officers of the executive departments or of such other body as Congress may by law provide, transmit to the President pro tempore of the Senate and the Speaker of the House of Representatives their written declaration that the President is unable to discharge the powers and duties of his office, the Vice President shall immediately assume the powers and duties of the office as Acting President. ${ }^{174}$

Section Four also has a failsafe: The President has the power to make a counterdeclaration that he or she is indeed able to discharge the powers and duties of the office. ${ }^{175}$ When this occurs, the Cabinet and the Vice President have four days to respond and either concede, or reassert the President's inability, and the dispute will then be up to Congress to resolve by a two-thirds vote of both Houses. ${ }^{176}$

The drafters of this amendment, including then-Senator Birch Bayh, explained to the Judiciary Committee that removal pursuant to this amendment is very different from impeachment. ${ }^{177}$ Impeachment can be a lucrative tool for the President's adversaries. ${ }^{178}$ In contrast, removal pursuant to Section Four requires the President's closest colleagues to believe he or she is incapacitated. ${ }^{179}$ Therefore, Section Four cannot be used for political purposes, but can only realistically be used in the most severe cases when "the helm is, effectively, unmanned." ${ }^{180}$ Further indicating that Section Four is only to be used in the most dire circumstances, this section has never been invoked to remove a President. ${ }^{181}$

173. U.S. CONST. amend. XXV.

174. Id. amend. XXV, § 4.

175. Id.

176. Id.

177. Presidential Inability and Vacancies in the Office of Vice President, S. Rep. No. 89-66, at 23 (1965).

178. Mark A. Graber, The Constitutional Politics of Impeachment, JURIST (Dec. 6, 2019), https://www.jurist.org/commentary/2019/12/mark-graber-politics-of-impeachment/ [https://perma.cc/A7WZ-M4QX] ("every effort to impeach a president has begun in the branch of government controlled by members of the rival party").

179. S. REP. No. 89-66, supra note 177, at 13 ("The combination of the judgment of the Vice President and a majority of the Cabinet members appears to furnish the most feasible formula without upsetting the fundamental checks and balances between the executive, legislative, and judicial branches. It would enable prompt action by the persons closest to the President, both politically and physically, and presumably most familiar with his condition. It is assumed that such decision would be made only after adequate consultation with medical experts who were intricately familiar with the President's physical and mental condition.").

180. Brian C. Kalt, What the 25th Amendment Is Really For, LAwFARE (Oct. 2, 2019, 8:00 AM), https://www.lawfareblog.com/what-25th-amendment-really [https://perma.cc/Z5EV-GRB8].

181. 25th Amendment, HIST., https://www.history.com/topics/united-states-constitution/25thamendment (last updated June 21, 2019) [https://perma.cc/HH3J-AAC6]. 


\section{B. The Fifty States}

The majority of states in the union have procedures for the removal of a state judge beyond impeachment. Currently, the District of Columbia and thirty-three states rely on a judicial inquiry commission, commission on judicial conduct, or another similar department to investigate and recommend to the highest court of that state the retirement or removal of a judge. ${ }^{182}$ In some cases, these commissions have the authority to independently act upon their recommendations. ${ }^{183}$ The governors of Kansas, Massachusetts, and New Jersey each have the authority to remove a judge based on a certification of incapacity. ${ }^{184}$ Two states, Delaware and Maryland, allow the removal of a judge for reasons including disability but not impeachable conduct, with a joint resolution of twothirds of the general assembly of the state. ${ }^{185}$

For an example of how one state responded to this issue, the Indiana Constitution provides that the Supreme Court of the state has original jurisdiction in "discipline, removal and retirement of justices and judges," 186 and it established by Article 7, Section 9 the Indiana Commission on Judicial Qualifications. ${ }^{187}$ Beyond providing the authority to investigate and hold hearings on complaints concerning Indiana judges, Indiana also requires mandatory retirement at age seventy-five for all state supreme court justices and court of appeals judges. ${ }^{188}$

Regarding removal of Indiana judges on the basis of disability, Article 7, Section 11 of the Indiana Constitution provides that "[o]n recommendation of the commission on judicial qualifications the Supreme Court may (1) retire such justice . . . for disability that seriously interferes with the performance of his duties and is or is likely to become permanent." 189 When the Commission recommends to the supreme court that one of its own justices should be retired, however, the constitution provides that "[n]o justice shall participate in the determination of such hearing when it concerns himself," leaving the decision to the four remaining justices on the Indiana Supreme Court. ${ }^{190}$

Indiana also adopted a statutory scheme in order to carry out the constitutional commands for retirement based on serious disability. The statute provides that the Indiana Rules of Evidence apply and that as insurance for a fair hearing, a judge or justice that has been adjudged incapacitated by Indiana's probate rules for guardianships is entitled to have his or her guardian "claim and

182. Methods of Judicial Selection: Removal of Judges, NAT'L CTR. FOR ST. CTS., $\mathrm{http}: / / \mathrm{www} . j u d i c i a l s e l e c t i o n . c o m / j u d i c i a l \_s e l e c t i o n / \operatorname{methods} /$ removal_of_judges.cfm?state $=$ (last visited Sept. 27, 2020) [https://perma.cc/2FYV-KYXR].

183. Id.

184. Id.

185. Id.

186. IND. CONST. art. $7, \S 4$.

187. Id. art. $7, \S 9$.

188. IND. CODE § 33-38-13-8 (2020).

189. Ind. CONST. art. 7, § 11.

190. Id. 
exercise any right and privilege and make any defense for the justice or judge with the same force and effect as if claimed, exercised, or made by the justice or judge if competent." 191

\section{The United Kingdom}

Across the Atlantic Ocean in the United Kingdom, the Constitutional Reform Act of 2005 contains a provision for compulsory medical retirement for its highest judges. ${ }^{192}$ A judge of the supreme court may have his or her office vacated if "the Lord Chancellor is satisfied by means of a medical certificate that" the supreme court judge "(a) is disabled by permanent infirmity from the performance of the duties of his office, and (b) is for the time being incapacitated from resigning his office." 193

This provision of the United Kingdom Constitutional Reform Act came about as a larger movement to transform the judiciary branch of the United Kingdom. ${ }^{194}$ Previously, the highest court of appeal in the country was the House of Lords, a legislative body part of the United Kingdom's Parliament. ${ }^{195}$ Recognizing that this was an "unusual role" for a legislative organization, the Constitutional Reform Act established the United Kingdom's first appellate supreme court entirely independent from Parliament. ${ }^{196}$ "The [Constitutional] Reform Act . . . was intended to "put the relationship between the executive, the legislature and the judiciary on a modern footing, which takes account of people's expectations about the independence and transparency of the judicial system."'197

The Constitutional Reform Act of 2005 notably provided a procedure for the removal of a permanently disabled supreme court judge from its inception. ${ }^{198}$ Additionally, the United Kingdom's higher court judges that serve life tenure have been subject to mandatory retirement, first at age seventy-five beginning in 1959, and then at age seventy since 1993. ${ }^{199}$ The introduction of mandatory retirement in the United Kingdom was motivated by a concern for the potential for mental failings and that the judiciary was out of touch with the rest of society. ${ }^{200}$ However, it was lowered in 1993, largely in order to create "judicial

191. IND. CoDE $\S \S 33-38-13-18$ to -19 (2020).

192. Constitutional Reform Act of 2005 , c. 4 , $\$ 36$ (Eng.).

193. Id.

194. Monica A. Fennell, Emergent Identity: A Comparative Analysis of the New Supreme Court of the United Kingdom and the Supreme Court of the United States, 22 TEMP. INT'L \& ComP. L.J. 279, 279-80 (2008).

195. Id. at 280 .

196. Id. at $279-80$.

197. Id. at 281.

198. Constitutional Reform Act of 2005, c. 4, § 36 (Eng.).

199. Mary L. Clark, Judicial Retirement and Return to Practice, 60 CATH. U. L. REV. 841, 872 (2011)

200. Id. at 884 . 
vacancies for women and racial and ethnic minorities to fill." ${ }^{, 201}$ While diversity is an entirely valid and positive motivation for mandatory retirement, this is in contrast to the rationale for many of the leading proposals for term limits or mandatory retirement for the United States Supreme Court, and indeed the argument made in this Note.

What this analytical overview of different jurisdictions and branches of government demonstrates is that not only have other areas encountered this problem, but also that an amendment resolving the problem is entirely possible. The solutions other governmental branches and jurisdictions use also provide guiding examples for directly addressing the incapacity problem on the United States Supreme Court. The Twenty-Fifth Amendment shows that even though a constitutional amendment is difficult to pass, it is not impossible. Section Four of the Twenty-Fifth Amendment also provides guidance for avoiding separation of powers issues and preventing partisanship from being a driving force for the removal from office. The fact that a majority of the states, as well as the United Kingdom since the inception of its supreme court, have proactively devised a solution to this issue provides additional support for the prudence of directly addressing the challenge for the United States Supreme Court.

\section{RESOLVING THE GAP}

As indicated in Part I of this Note, none of the current constitutionally sound procedures for removal or retirement of a member of the Supreme Court are adequate to address a ghost Justice. To prevent an incapacitated Justice from remaining on the bench, long after they are able to contribute to the Court due to severe mental or physical disability, the United States Congress should propose a constitutional amendment substantially similar to Section Four of the TwentyFifth Amendment that applies to members of the Supreme Court of the United States with additional third-party safeguards, modeled after the Constitutional Reform Act of 2005 in the United Kingdom. ${ }^{202}$

An ideal amendment would provide that where a majority of the members on the Supreme Court communicate to the Senate Committee on the Judiciary and to the President that a member of the bench is unable to discharge the duties of his or her office and is incapacitated from resigning, and the Senate Committee and the President are satisfied with a medical certificate or record that the Justice is in fact disabled or incapacitated to the extent that it prevents his or her resignation or performance, the Justice's office may be declared vacated.

Drafting the amendment to model the Twenty-Fifth Amendment to the United States Constitution, with the additional safeguard of a medical certificate, avoids any separation of powers issues in the same way the Twenty-Fifth Amendment does. ${ }^{203}$ Requiring a Justice's closest colleagues to publicly raise the issue ensures that it will not be done except during extreme circumstances. The history of the

201. Id.

202. Constitutional Reform Act of 2005, c. 4, § 36 (Eng.).

203. See supra Part IV.A. 
Supreme Court protecting members that were potentially incapacitated from public scrutiny also defends against the argument that a political majority on the Court could remove a minority member. ${ }^{204}$ This would also require an unprecedented extreme partisan majority on the Court.

Difficult problems, such as severe incapacity on the Supreme Court, are rarely solved with simple solutions. The constitutional amendment proposed in this Note attempts to solve this difficult problem in the best way possible. Recognizing that constitutional amendments are notoriously hard to pass, an amendment avoids the fundamental issues associated with prior proposals and other contemporary arguments. A constitutional amendment is necessary both to supply an adequate means to remove an incapacitated Justice and to comply with the existing constitutional provisions. In order to understand why a constitutional amendment similar to the one proposed in this Note is necessary, the following subsections discuss prior proposals and other arguments made to address incapacity on the bench.

\section{A. Age Limits}

Several proposals altering judicial tenure have been made and submitted to Congress in recent history, but for varying reasons they were ultimately unsuccessful. The first two would have required mandatory retirement for Supreme Court Justices at either age seventy or seventy-five. ${ }^{205}$ The first round of proposals for age-related mandatory retirement was unsuccessful due to lack of support from President Roosevelt. ${ }^{206}$ The second movement for mandatory retirement at age seventy-five received support from retired Justice Owen J. Roberts. ${ }^{207}$ This particular movement during the 1950 s ultimately died due to a lack of public support and a change in majority control of Congress. ${ }^{208}$

However wise age-based mandatory retirement proposals may have seemed at the time, or even now, their major flaw is the static age at which a Justice would be required to retire. As demonstrated by the proposed amendments' initial failures, the Constitution is notoriously hard to change. ${ }^{209}$ An amendment relying directly upon the extremely individual, but generally increasing, life expectancy will inevitably prove to be unworkable and will fail the test of time as longevity continues to rise. ${ }^{210}$ For example, imagine that age-based mandatory retirement was included in Article III of the Constitution at the time of its ratification. Life

204. See supra Part II.

205. Garrow, supra note 20, at 1019-24.

206. Id. at 1026.

207. Id. at 1032 .

208. Id. at 1041 .

209. Drew DeSilver, Proposed Amendments to the U.S. Constitution Seldom Go Anywhere, Pew Res. CTR. (Apr. 12, 2018), https://www.pewresearch.org/fact-tank/2018/04/12/a-look-atproposed-constitutional-amendments-and-how-seldom-they-go-anywhere/ [https://perma.cc/R88LVX43].

210. See supra Part III. 
expectancy of individuals in the Americas when the Supreme Court was established is estimated to have been between thirty-four and thirty-six years old. ${ }^{211}$ A little over 100 years later, life expectancy in America in 1900 was 47.3 years old. ${ }^{212}$ In 1950, life expectancy had jumped to be 68.2 years old, and in 2000, it was 76.8. ${ }^{213}$ Life expectancy in the United States has nearly doubled since the time that the Supreme Court was established. ${ }^{214}$ Let the numbers speak for themselves: age-based mandatory retirement cannot remain functional and is counterintuitive if the Supreme Court is expected to remain in existence for another 200 years.

A further concern with age-based term limits is the inherent age discrimination. Although the Supreme Court has found that age-based mandatory retirement has a rational basis and does not violate the Equal Protection Clause for purposes of states' policies adopting this form of compulsory retirement for state court judges, it still relies upon a harmful stereotype that once reaching a certain age, all individuals lack the mental capacity to continue doing the work they have done for years prior. ${ }^{215}$ Indeed, the Court refused to firmly declare that all older judges suffer diminished abilities. ${ }^{216}$ Justice Sandra Day O'Connor noted that the mandatory retirement provision at issue in Gregory v. Ashcroft was "founded on a generalization." ${ }^{217}$ Critically, she says:

It is far from true that all judges suffer significant deterioration in performance at age 70. It is probably not true that most do. It may not be true at all. But a State does not violate the Equal Protection Clause merely because the classifications made by its laws are imperfect. ${ }^{218}$

The Supreme Court simply cannot settle for an imperfect classification that would likely force out highly capable Justices.

This stereotype is especially harmful since Supreme Court Justices are

211. Max Roser et al., Life Expectancy, OuR WORLD IN DATA, https://ourworldindata.org/lifeexpectancy\#citation (last updated Oct. 2019) [https://perma.cc/SED7-X53Q]; J. David Hacker, Decennial Life Tables for the White Population of the United States, 1790-1900, Hist. METHODS: J. QuANTiTATIVE \& InTERDisC. Hist tbl.1 (2010), https:/www.ncbi.nlm.nih.gov/pmc/articles/ PMC2885717/ [https://perma.cc/DQ59-48D6].

212. Health, United States, 2018, Ctrs. For Disease Control \& Prevention tbl.4 (2019), https://www.cdc.gov/nchs/hus/ataglance.htm [https://perma.cc/Q4RZ-QYG9].

213. $I d$.

214. Xu et al., supra note 142, at 1 (life expectancy in 2018 of 78.7).

215. See Gregory v. Ashcroft, 501 U.S. 452 (1991); see also Melissa Dittmann, Fighting Ageism, 34 Monitor on Psychol. 50, 50 (May 2003), https://www.apa.org/monitor/may03/ fighting [https://perma.cc/RL9B-8NGG] ("[T]hose who are 60 or older may all too often find themselves the victims of ageism. In fact, in a survey of 84 people ages 60 and older, nearly $80 \%$ of respondents reported experiencing ageism — such as other people assuming they had memory or physical impairments due to their age.").

216. Gregory, 501 U.S. at 473.

217. Id.

218. Id. (internal citations and quotations omitted). 
appointed to life terms with the general expectation that they will serve as long as they reasonably can, or until their death, while state court judges often serve limited terms or are subject to retention elections. ${ }^{219}$ A removal procedure based on incapacity avoids the imperfect generalization that age-based mandatory retirement relies upon. The same legitimate interest the people of Missouri had in Gregory v. Ashcroft "in maintaining a judiciary fully capable of performing the demanding tasks that judges must perform," however, is equally applicable to the interest all Americans have in the capability of the Justices of the Supreme Court. ${ }^{220}$ The rational bases for the mandatory retirement provision at issue in Gregory are analogous to the many justifications for a removal procedure based on incapacity discussed in this Note. Because of the legitimate interest in maintaining a fully capable judiciary, Justice O'Connor identified that the state "may therefore wish to replace some older judges" because "[i]t is an unfortunate fact of life that physical and mental capacity sometimes diminish with age."221 Rather than settling for an imperfect generalization however, a constitutional amendment providing a procedure for removal based on incapacity better solves this "tedious" and "perplexing" problem. ${ }^{22}$

\section{B. Term Limits}

Additional arguments are often made for imposing term limits on members of the Supreme Court. ${ }^{223}$ However, term limits fail to directly address the problem of incapacity on the bench and also come with significant problems. Term limits may "discourage qualified individuals from accepting a nomination to the Court." ${ }^{224}$ Term limits also have the potential to "wreak havoc on doctrinal stability" on which American law heavily depends. ${ }^{225}$ However, the most dangerous concern is the substantial threat to judicial independence. ${ }^{226}$ Life tenure was established at the time of the founding with the express purpose of protecting judicial independence, and such independence should be maintained. ${ }^{227}$

Alexander Hamilton's Federalist No. 78 eloquently and thoroughly defends

219. Id. at 472-73 (1991); Mo. Const. art. V, $\S 19$ (Supreme Court justices and Court of Appeals judges serve 12-year terms; Circuit Court judges serve for 6 years.).

220. Gregory, 501 U.S. at 472.

221. Id.

222. Id. at 471 (quoting O’Neil v. Baine, 568 S.W.2d 761, 766-67 (Mo. 1978)).

223. See, e.g., Leading Constitutional Scholars Propose Resolution to the Supreme Court Confirmation Madness, FIX THE COURT (June 29, 2017), https:/fixthecourt.com/2017/06/ tlproposalrelease/ [https://perma.cc/X2Z5-LVAV].

224. William G. Ross, The Hazards of Proposals to Limit the Tenure of Federal Judges and to Permit Judicial Removal without Impeachment, 35 VILL. L. REV. 1063, 1091 (1990).

225. Suzanna Sherry \& Christopher Sundby, Academic Highlight: The Risks of Supreme Court Term Limits, SCOTUSBlog (Apr. 5, 2019, 1:29 PM), https://www.scotusblog.com/2019/04/ academic-highlight-the-risks-of-supreme-court-term-limits/ [https://perma.cc/M4AB-L8NX].

226. Ross, supra note 224, at 1089.

227. Sherry \& Sundby, supra note 225. 
the current framework of the federal judiciary, specifically life tenure. ${ }^{228}$ Hamilton's essay identifies that with neither the power of the purse nor the sword, the judiciary is the weakest of the three governmental branches and therefore must be independent from the others to ensure that "the general liberty of the people" is protected. ${ }^{229}$ Hamilton argues that "permanency in office" is "an indispensable ingredient" in the Constitution "to secure a steady, upright, and impartial administration of the laws." ${ }^{230}$ Federalist No. 78 also identifies that a temporary duration in office would discourage the highly qualified individuals needed to protect the liberty of the people from accepting a position on the Court. ${ }^{231}$ Not only is life tenure an indispensable ingredient in the Constitution, limiting the length of service on the Supreme Court is wholly inadequate to address the possibility that severe incapacity could occur long before a Justice's proverbial term is up. Disrupting life tenure in favor of term limits "would only introduce foreign variables into a once-sterile environment, presenting no benefits in the way of increasing judicial accountability while resulting in a multitude of unintended consequences that inhibit the most sacred functions of our courts."232

\section{Statutory Measures}

Currently, the only procedure to involuntarily remove a Justice from the Supreme Court is through impeachment; therefore, any statutory measure attempting to put forth other forms of removal are unconstitutional. ${ }^{233}$ In his book discussing the historic impeachments of Justice Samuel Chase and President Andrew Johnson, Justice Rehnquist says it best:

Today we think of the Supreme Court as the well-established and thoroughly independent head of the judicial branch of the federal government. While many people inevitably disagree with many of its decisions, the thought of changing its membership by means other than those contemplated by the Constitution would be firmly rejected by public opinion. ${ }^{234}$

Proposals made in the 1970s demonstrate the certain failure of statutory measures providing for alternate routes of judicial removal. ${ }^{235}$ One bill that was

228. See The Federalist No. 78 (Alexander Hamilton).

229. Id.

230. Id.

231. Id.

232. Shaheen Nouri, Life Tenure and the Dynamic of Judicial Independence in the Federal System, 5 Stetson J. Advoc. \& L. 155, 182 (2018), https://www2.stetson.edu/advocacyjournal/life-tenure-and-the-dynamic-of-judicial-independence-in-the-federalsystem/\#I_An_Early_History_of_Life_Tenure [https://perma.cc/B4BK-LFEM].

233. See U.S. Const. art. III, § 1; Turley, supra note 6.

234. William H. Rehnquist, Grand Inquests: The Historic Impeachments of Justice Samuel Chase and President Andrew Johnson 128 (1999).

235. Judicial Tenure and Discipline-1979-80: Hearings on H.R. 622, H.R. 1227, H.R. 4044, 
originally introduced as the Judicial Tenure Act established a procedure for the removal of federal judges including Supreme Court Justices. ${ }^{236}$ From the start, there were serious concerns about the constitutionality of such a bill. ${ }^{237}$ The Committee on Federal Legislation advised that the bill not be enacted mostly due to the belief that it was unconstitutional. ${ }^{238}$ Eventually, the Judicial Tenure Act was revised, and it became the Judicial Council Reform and Judicial Conduct and Disability Act of $1980 .{ }^{239}$ Its provisions on removal based on disability apply only to federal judges below the Supreme Court. ${ }^{240}$

"The U.S. Constitution is famously difficult to amend." ${ }^{241}$ In 2018, Pew Research Center determined that "[o]f the roughly 12,000 amendments proposed since the Constitutional Convention, only 33 have gone to the states for ratification, and just 27" were actually added to the Constitution. ${ }^{242}$ It is impossible to ignore this immense hurdle. However, the same study conducted by Pew Research Center identified that "many, if not most, proposed amendments have a distinct partisan tinge to them." ${ }^{243}$ The two-thirds vote required by both houses of Congress that necessitates "a degree of political consensus" suggests that at least part of the difficulty of amendments is attributable to the common practice of proposing politically driven amendments. ${ }^{244}$ The Twenty-Fifth Amendment demonstrates that with the right motivation, the necessary political consensus is possible with regard to incapacity among the highest ranks of our federal government. ${ }^{245}$ While a constitutional amendment is "famously difficult," it is the correct solution and certainly a more viable solution than statutory measures that must fail.

\section{CONCLUSION}

Walking through the history of the Supreme Court plainly demonstrates that ghosts of the Supreme Court emerge with enough regularity to cause concern for the lack of a remedy. Evidenced by the previous proposals that have been made, lawmakers are well aware of the inability of the government to deal with the problem of incapacitated Justices on the Supreme Court. The Twenty-Fifth Amendment shows that while difficult, amending the Constitution is not impossible with the right impetus. The Twenty-Fifth Amendment providing for

H.R. 4115, H.R. 4641, H.R. 5873, H.R. 6330, and S. 1873 Before the Subcomm. on Courts, Civil Liberties \& the Admin. of Justice of the H. Comm. on the Judiciary, 96th Cong. 1-2 (1979-1980).

236. $I d$.

237. $I d$.

238. $I d$.

239. 28 U.S.C. $\S \S 351-364$ (2019).

240. Id.

241. DeSilver, supra note 209.

242. $I d$.

243. Id.

244. U.S. CONST. art. V; DeSilver, supra note 209.

245. See supra Part IV.A. 
removal of the President if he is unable to carry out his duties also leads lawmakers looking for a solution to the logical conclusion that a similar amendment for the Supreme Court would be the most likely solution to be accepted by the Court, by other lawmakers, and ultimately by the states. A constitutional amendment following a similar procedure as the Twenty-Fifth Amendment with additional safeguards modeled after an amendment in the United Kingdom efficiently fills the gap left by the Constitution as it currently stands and is wisely proactive, handling the problem now before an incapacitated Justice remains as a ghost on the Supreme Court, leaving controversy and extensive damage to the Court's reputation in its wake. 